\title{
RESILIENCE OF THE TERRITORY UNDER BIG CITY INFLUENCE: RISKS, VULNERABILITY, NEW MANAGEMENT APPROACHES
}

\author{
Olena DENYSENKO \\ Taras Shevchenko National University of Kyiv, Ukraine \\ vid_dil@meta.ua
}

\begin{abstract}
Over the last decades international approaches to determining the resilience of the territory and key mechanisms of its achieving substantially transformed. It is reflected in the goals, objectives and activities of their implementation of Hyogo Framework for action (2005-2015) and Sendai Framework for disaster risk reduction (2015-2030). In Ukraine these approaches are almost not implemented in practice of emergency management, just some of the internationally recognized principles are contained in the Conception of natural hazards and disasters risk management (2014). At the same time it is necessarily to make the sense of some new categories for Ukrainian research and management fields like vulnerability, sensitivity of the territory, response capacity, prevention and mitigation of the risks which are central in the International Strategy for Disaster Reduction.

In the paper we analyze the essence of these categories and justify the necessity of their usage for disaster management mechanism transformation, in particular for making strategies on governmental and regional levels. For this aim we analyze the resilience of the territory under big city influence by the case of Kyiv oblast as one of the most vulnerable regions in Ukraine. Revealed peculiarities reflect rather significant differences inside the territory under big city influence by the level of dangerous objects localization and sensitivity, which must be taking into account for implementing the strategy of disaster risk reduction on the regional and local levels. Special accent in the paper we make on the bringing in correspondence the Ukrainian governmental and regional politics in disaster risk management to internationally recognized priorities: broadening of the essence of the category of risk, forming the program of the actions for disaster risk reduction, taking into account the vulnerability of the territory, enhancement of the regional and local levels of the disaster management, engagement of the public participation in disaster management to create disaster-resistant territories.
\end{abstract}

Key words: safety, risk, vulnerability of the territory, big city, disaster risk management, GIS.

UDC: $911.3: 351$

\section{БЕЗПЕКА ТЕРИТОРІЇ В ЗОНІ ВПЛИВУ ВЕЛИКОГО МІСТА: РИЗИКИ, ВРАЗЛИВІСТЬ, НОВІ УПРАВЛІНСЬКІ ПІДХОДИ}

\author{
Олена ДЕНИСЕНКО \\ Київський начіональний університет імені Тараса Шевченка, Україна \\ vid_dil@meta.ua
}

\begin{abstract}
Анотація: В останній час міжнародні підходи до визначення безпеки території і ключові механізми її досягнення істотно трансформувалися, що відображене у цілях та заходах з їхнього впровадження міжнародних рамкових угод - Хіозької (20052015рр.) та Сендайської (2015-2030рр.). В Україні ці підходи на управлінському рівні майже не імплементовані, і лише окремі 3 них містяться у Концепції управління ризиками виникнення надзвичайних ситуацій техногенного та природного характеру (2014р.). Водночас змістовного наповнення і осмислення потребують відносно нові для дослідницького та управлінського середовища категорії - вразливості, чутливості території, здатності реагувати на загрози, попередження та пом'якшення ризиків, які займають принципово важливе місце в міжнародній стратегії зниження ризиків.

У статті ми пропонуємо аналіз змісту цих категорій та обгрунтовуємо доцільність їх врахування при трансформації управлінського механізму, зокрема при визначенні стратегії на державному та регіональному рівнях. 3 цією метою ми аналізуємо стан безпеки території в зоні впливу великого міста на прикладі Київської області - одного з найбільш вразливих регіонів в Україні. Виявлені особливості засвідчують достатньо значну диференціацію території в зоні впливу великого міста за рівнем загроз та чутливості, що потребує врахування при запровадженні стратегії зниження ризиків на регіональному та місцевому рівнях. Окремий акцент у статті ми робимо на доцільності приведення у відповідність механізму реалізації державної і регіональної політики у цій сфері до визначених на міжнародному рівні пріоритетів: розширення змістовного наповнення категорії ризику, формування програми заходів зі зниження ризиків з урахуванням вразливості території, посилення регіонального та місцевого рівнів управління, залучення громадськості до управлінського механізму з метою формування більш стійких до загроз і ризиків територій.
\end{abstract}

Ключові слова: безпека, ризик, вразливість території, велике місто, механізм управління ризиками, ГІС.

УдК: $911.3: 351$

Вступ. Постановка проблеми. Останні два десятиліття у світі позначилися не лише значними природними i техногенними катастрофами 3 людськими жертвами і економічними збитками, але

(C) О. Денисенко й зміною парадигми у сфері дослідженні безпеки території. 3'явилися нові концептуальні підходи, що стали базисом формування безпеки та реалізації управлінського механізму. В Україні ці підходи майже не імплементовані, а отже, потребують додаткового вивчення, переосмислення, виходячи 
3 реалій функціонування українських регіонів. 3 цією метою проаналізовано стан безпеки особливо динамічної та вразливої території - регіону, що перебуває під впливом великого міста.

Аналіз останніх досліджень і публікацій, виходячи 3 цілей статті, висвітлений дещо розширено та міститься нижче.

Формулювання цілей статті. Постановка завдання. До основних цілей статті належать наступні:

- Аналіз сучасних концептуальних підходів у сфері дослідження безпеки території та їх відмінностей зі змістом вітчизняних концепцій;

- Виявлення основних закономірностей, що характеризують стан безпеки території у зоні впливу великого міста;

- Розробка рекомендацій щодо доцільності вдосконалення управлінського механізму в Україні, зокрема на регіональному рівні, відповідно 3 існуючими світовими підходами.

Виклад основного матеріалу. Фундаментальні відмінності між вітчизняними й іноземними підходами в розумінні найважливіших концептуальних категорій зумовлюють необхідність дещо розширеного висвітлення існуючих підходів та виявлення найбільш релевантних із них 3 точки зору можливого застосування для аналізу стану безпеки території.

Свого роду концептуальним аналогом до категоpiï «безпеки», виходячи зі свого дещо ідеалістичного за змістом навантаження, в західній літературі може розглядатися поняття стійкості (resiliency) територіальної спільноти, передусім стійкості міст, до виникнення небезпек. При цьому під стійкістю, або інакше кажучи пружністю, розуміють здатність соціальної або екологічної системи реагувати на загрози, зберігаючи при цьому базову структуру i спосіб функціонування, здатність до самоорганізації, а також здатність адаптуватися до стресів і змін[2]. Особливо важливе місце в структурі категорії стійкості належить соціальному виміру стійкості, що передбачає аналіз різних характеристик населення в контексті підвищення рівня готовності до запобігання, виникнення та відновлення після можливих небезпек. У цьому контексті загальна мета посилення стійкості міст до виникнення ризиків, реалізована в концепціï resilient cities, відповідає концептуальному баченню та стратегічній меті підвищення безпеки розвитку території.

Водночас методологічно та методично існують дуже значні відмінності між світовими та традиційними українськими підходами. Передусім ці відмінності стосуються наступного:

1. Значне розширення змісту категорії «ризик», перетворення її з вузької технічної до значно ширшої за концептуальним навантаженням соціальноекономічної, коли винятково технічна оцінка більше не розглядається як достатня і повна інформаційна складова про можливість виникнення небезпек, особливо на регіональному і локальному рівні, що відповідно визначає обмеженість їі використання для розробки управлінських рішень;
2. Визнання ризику як реальної складової суспільного життя, що потребує не лише оцінки та реагування на негативні події, але й включає інші важливі етапи: «пом'якшення» ризиків, формування готовності, реагування на небезпечні події, відновлення та реконструкція, що $є$ складовими концепції управління ризиками;

3. Застосування багаторівневого просторового підходу до аналізу та управління ризиками 3 акцентом на регіональному та локальному рівні, де найбільш повною мірою можна застосувати принципи концепції зниження ризиків;

4. Імплементація альтернативних підходів до централізованого (технократичного) типу управління на основі принципу партисипативності 3 використанням нових, зокрема геоінформаційного, підходів та залученням громадянського суспільства до контролю і управління.

Як видно, кожне з цих положень значною мірою стосується сфери управління як активної діяльнісної складової, що безпосередньо впливає на стан безпеки регіону. Розглянемо їх дещо детальніше.

Категорія ризику та тісно пов'язані 3 ним поняття, фактично, є основою західноєвропейських та світових підходів. Проте їі змістовне навантаження суттєво відрізняється від прийнятого в Україні. В межах традиційного підходу, що домінує в Україні, ризик здебільшого розуміється як ймовірність виникнення тієї чи іншої негативної події, тривалий час розвивалися статистичні методи його оцінки. Таким чином, категорія ризику навіть тоді, коли мова йшла про регіональний аналіз, переважно залишалася у змістовному полі технічних підходів. Водночас у світі активний відхід від технічного розуміння ризику відбувся ще в кінці $80-x$ років паралельно зі становленням концепції зниження ризиків, що розвивалася в рамках парадигми збалансованого розвитку території. Так, проголошення Генасамблеєю ООН 90-х років як Міжнародної декади зі зниження природних катастроф стало передумовою розвитку i формування сучасної концепції зниження ризику небезпек (disaster risk reduction), що, зокрема, знайшло відображення в прийнятті Хіозької (на період 2005-2015pp.) та Сендайської (2015-2030pp.) рамкових угод зі зниження ризику катастроф. Зміст концепції зниження ризику катастроф визначається як систематичні зусилля, спрямовані на «зниження схильності до виникнення небезпек, зниження вразливості людей і майна, раціональне управління земельними ресурсами і природним середовищем, вдосконалення готовності до небажаних явищ та їх завчасне попередження» [7].

Змістовно категорія ризику в сучасних дослідженнях розглядається як поєднання ймовірності виникнення події та ii негативних наслідків [2]. При цьому потенційні негативні наслідки розглядаються як похідна від вразливості території. Вразливість (vulnerability) може бути визначена як результат дії фізичних, соціальних, економічних чинників та середовища, що підвищує сприйнятливість спільноти до виникнення небезпек[6]. 
Аналіз вразливості регіонів до небезпечних подій, у тому числі їх окремих видів, наразі $\epsilon$ домінуючим підходом до аналізу ризиків виникнення небезпек та визначення оптимальної стратегії управління ними. Сильні сторони концепції оцінки вразливості особливо вдало реалізується у випадку невеликих територіальних спільнот, де є специфічне поєднання різних чинників, що визначають вразливість до небезпек. Так, скажімо, категорія вразливості дозволяє розрізняти і здійснювати різні управлінські стратегії для територій, що схильні до одного типу загроз, але 3 різною частотою чи інтенсивністю небезпек, різним рівнем щільності населення та зосередженого економічного потенціалу, різною здатністю відповідати на загрози. Можливість враховувати відповідні аспекти реалізується завдяки розробленій структурі категорії вразливості [2, 5], яка включає декілька складових, спрямованих на виявлення специфічних рис і особливостей регіону, що визначають його чутливість до різного роду загроз. Багатоаспектна структура вразливості передбачає аналіз схильності території до настання небезпечних подій, аналіз чутливості 3 урахуванням зосередженого на території соціально-економічного потенціалу, а також оцінку регіону відповідно до його здатності реагувати на загрози.

Таким чином, аналіз вразливості території $\epsilon$ базовим підходом в сучасних дослідженнях безпеки регіону та формування стратегії його стійкості, оскільки враховує найбільш різносторонні аспекти формування ризику та його можливі наслідки, дає змогу розробляти найбільш адекватну управлінську стратегію, деталізовану відповідно до специфіки того чи іншого регіону.

3 методичної точки зору одним 3 найбільш цікавих регіонів України для виявлення вразливості до техногенних ризиків $є$ Київська область, для якої характерний, з одного боку, достатньо високий рівень загроз, значний зосереджений інфраструктурний та соціально-економічний потенціал та висока щільність населення, які визначають високу чутливість регіону до потенційних загроз. 3 іншого боку, потенційна здатність до пом'якшення цих викликів та реалізації вдалої управлінської стратегії $€$ також дещо вищою порівняно $з$ іншими регіонами. Досить вдала структурна трансформація економіки, що відбулася в більшості міст Київської області, та відносно сприятлива соціально-економічна ситуація порівняно з іншими регіонами дозволяють розглядати цей регіон як свого роду модельний 3 точки зору формування майбутньої стратегіï управління ризиками загалом.

Говорячи про потенційні ризики та рівень вразливості території Київської області, передусім варто відзначити їх безпосередній взаємозв'язок 3 наявністю потужного метрополітарного ядра - міста Києва. Ця особливість, коли стан безпеки регіону визначається потужними економічними центрами, характерна для всіх регіонів, проте особливо це проявляється у випадку великих міст, які $\epsilon$ осередками соціально-економічного притягання та визначають територіальну організацію всіх видів діяльності на прилеглій території. Причому інтенсивність впливу великого міста, у даному випадку Києва, на стан вразливості до ризиків прилеглої території тим вища, чим вищою $\epsilon$ тіснота зв'язків 3 ядром - розселенських (зростання щільності населення), інфраструктурних (вища щільність як окремих об'єктів, зокрема складських приміщень, логістичних комплексів, так і мережі шляхів сполучення), економічних (вища активність господарської діяльності) та ін.

Вплив великого міста на формування рівня ризиків та вразливості прилеглої території можна охарактеризувати двояко: як прямий i непрямий вплив. Прямий вплив пов'язаний з тим, що частина приміської території потрапляє у потенційну зону враження у випадку виникнення небезпечних ситуацій на об'єктах, що безпосередньо розміщені в ядрі. Непрямий вплив міста є наслідком тісної функціональної взаємодії центру 3 приміською територією: ядро, фактично, здійснює визначальний вплив на просторову організацію всіх видів діяльності на прилеглій території, високу щільність розселенської мережі, сприяє формуванню розвиненої транспортної мережі та інфраструктури, високої щільності потоків. Це всі ті чинники, які з одного боку, визначають високу чутливість території до природно-техногенних небезпек, а з іншого, завдяки своїй ролі у підвищенні рівня розвитку регіону сприяють реалізації стратегії зниження ризиків.

Тому питання безпеки регіону довкола великого міста - це значною мірою питання інтенсивності зв'язків регіону з ядром.

У цьому зв'язку одне 3 важливих методологічних питань, яке виникає, це питання, в яких межах доцільно аналізувати територію як таку, стан безпеки якої значною мірою визначається великим містом, що $\epsilon$ ii соціально-економічним ядром. Варіантів відповідей може буде декілька, і вони залежать від того, який підхід використаний. Розглядають три підходи: морфологічне, функціональне і адміністративне розмежування [2].

Щодо морфологічного розмежування, то в якості базового критерію для визначення морфологічних меж міської та приміської території може бути використаний показник, що відображає ключові відмінності між способами функціонування території. Наприклад, 3 метою оцінки температурних впливів на міські території та приміські зони у дослідженні Європейського центру кліматичних змін, вразливості та адаптації (ЕТСССА) використаний такий критерій, як режим землекористування та структура рослинного покриву, що дозволяє вдало відобразити взаємозв'язок між режимом функціонування міст і приміської зони та формуванням термальних ефектів. У якості подібного критерію для виявлення морфологічних меж міської території та приміської зони з метою аналізу інтегральної схильності до ризиків та виявлення рівня вразливості можуть бути використані показники щільності населення, забудови території та активності господарської діяльності. 
Функціональний підхід у визначенні меж приміської території пов'язаний з ідеєю виконання містом ядром цілої низки важливих функцій, що не обмежуються лише економічними. Такі функції реалізуються не лише в межах міста-ядра, але й на приміській території, що тісно з ним пов'язана. У відповідності з цим, ідея функціонального підходу у визначенні меж приміської зони пов'язана із встановленням меж території, що найбільш тісно пов'язана 3 містом-ядром множиною зв'язків, та, фактично, має єдину, спільну з ним, функціональнопросторову структуру. Індикаторами для виявлення меж у цьому випадку можуть бути соціально-побутові зв'язки жителів, наявність та інтенсивність ритмів, у ході яких вони реалізуються.

Нарешті використання адміністративного підходу попри деяке спрощення проблеми, яке виникає на перший погляд, розширює можливості для аналізу завдяки залученню низки показників, по яких статистичний облік ведеться в адміністративних межах. Причому межі можуть бути розглянуті у вузькому розумінні - власне, межі самого міста і широкому - межі столичного регіону. В Україні використання такого підходу на даний час $\epsilon$ обмеженим у зв'язку з відсутністю адміністративно визначеного столичного регіону, хоча його виділення і планується реалізувати в ході адміністративної реформи.

Варто відзначити, що в одному дослідженні може бути реалізоване поєднання декількох підходів для відображення специфіки тих чи інших процесів.

Для цілей нашого дослідження зупинимося на адміністративно визначених межах Київської області. Хоча це, безумовно, більша за площею територія, ніж та, яка морфологічно і функціонально найбільш тісно пов'язана 3 Києвом та на яку місто здійснює найвищий вплив, все ж такий підхід $\epsilon$ виправданим та дозволить реалізувати декілька важливих задач.

По-перше, виявити диференціацію, як за рівнем потенційних загроз, так і рівнем вразливості території, що формує приміську зону Києва та більш віддалених, периферійних в межах області районів 3 нижчим рівнем соціально-економічного розвитку.

По-друге, враховувати отримані результати при формуванні управлінської стратегії зниження існуючих ризиків та пом'якшення рівня вразливості територіїдо можливих загроз, оскількиуправлінський механізм пов'язаний 3 існуючим адміністративним поділом, а отже, найбільш вдало управлінські задачі можуть бути реалізовані для регіонального рівня 3 подальшою деталізацією для локального рівня.

Київська область є регіоном 3 достатньо високим рівнем зосередження об'єктів техногенної небезпеки: їх на території більше п'ятисот, проте рівень їх локалізації досить нерівномірний i визначається загальними закономірностями розвитку регіону в зоні тяжіння великого міста. До них належать:

Виражений радіально-кільцевий тип територіальної структури, при якому вплив ядра на територію затухає по мірі віддалення від нього, а відповідно, знижується і рівень техногенного навантаження та ризиків, які поза приміською територію пов'язані передусім 3 іншими соціальноекономічними центрами, що є в регіоні;

- Формування приміської зони, що найбільш тісно пов'язана 3 містом-ядром i в межах якої спостерігається найвищий рівень вразливості у зв'язку 3 високим рівнем концентрації потенційно небезпечних об'єктів, а також високим рівнем чутливості території до виникнення небезпек. Цьому сприяють висока концентрація населення у потенційній зоні враження та підвищений рівень техногенних ризиків;

- Яскраво виражені основні вектори впливу міста-ядра, пов'язані з транспортними магістралями, що відображає один з ключових чинників формування підвищеного ризику регіону в зоні впливу великого міста. Висока щільність шляхів сполучення та транспортних потоків, зосередження транспортнологістичної інфраструктури розглядається як додатковий фактор формування ризику, 3 одного боку, та підвищення вразливості території, з іншого.

Необхідно зазначити, що названі чинники та інтенсивність їх прояву значною мірою залежать від соціально-економічного потенціалу та рівня розвитку самого міста, визначаючи як загальний рівень техногенної небезпеки на прилеглій території, так і структуру ризиків, а також здатність території відповідати на можливі загрози та пом'якшувати їх.

Загалом можна виділити такі основні закономірності, що визначають рівень можливих загроз та чутливість території Київської області до виникнення небезпек.

1. Серед об'єктів техногенної небезпеки, розміщених на території області, промислові об'єкти відіграють порівняно незначну роль, тоді як основне місце належить інфраструктурним за своєю суттю об'єктам - нафтобази, автозаправні станції, газорозподільні станції, що належать до категорії пожежовибухонебезпечних об'єктів.

Структура можливих ризиків і загроз в регіоні значною мірою залежить від компонентної структури господарства. Та галузева трансформація, що відбулася в Києві, починаючи з 90-х років, значною мірою видозмінила характер можливих загроз, як у самому місті, так і на прилеглій території. Сьогодні в структурі небезпечних промислових об'єктів Київської області переважають підприємства харчової промисловості.

Інші небезпечні об'єкти - об'єкти транспорту (автомобільні і залізничні мости, залізничні станції), об’єкти водопостачання та водовідведення (водозабірні свердловини, насосні станції, очисні споруди, водопровідні мережі, системи каналізації), об'єкти теплопостачання (ТЕЦ, котельні, теплові пункти та мережі), газо- i енергопостачання (трансформаторні підстанції, ЛЕП) - переважно перебувають у задовільному стані. Це відрізняє Київську область від інших регіонів та відображає вищу здатність до пом'якшення можливих загроз завдяки вищому рівню соціально-економічного розвитку.

2. Виражена концентрація потенційно 
небезпечних техногенних об'єктів у приміській зоні Києва. На п'ять районів, що безпосередньо межують 3 містом - Вишгородський, Києво-Святошинський, Обухівський, Бориспільський та Броварський припадає понад третина усіх об'єктів техногенної небезпеки, що знаходяться в Київській області. Особливо висока частка Києво-Святошинського району (об'єкти розміщені уздовж кільцевої дороги, довкола м.Ірпінь, м.Буча) та Броварського району (рис. 1). Фактично, це відображає два найвищі осередки концентрації потенційно небезпечних об’єктів у приміській зоні - безпосередньо довкола м. Києва у західному та східному напрямах. Загальною для приміської зони є тенденція розосередження небезпечних об'єктів: переважно вони не пов'язані $з$ містами-основними центрами приміської території, що відрізняє цю зону від іншої частини регіону.

У периферійних (за розміщенням) районах Київської області рівень зосередження небезпечних техногенних об'єктів, а відповідно, і рівень ризиків та чутливості території, $\epsilon$ відчутно нижчим. У більшості з них кількість таких об'єктів не перевищує десяти: Володарський, Тетіївський, Ставищенський, Таращанський, Богуславський, Яготинський, Згурівський, Баришівський, що значною мірою відображає нижчий рівень соціально-економічної активності цієї території.

3. Виразно виділяються основні ареали зосередження об'єктів техногенної небезпеки поза приміською зоною. Вони пов'язані з основними магістралями, що розташовані у західному, південно-західному та південно-східному напрямах: Київ-Ковель, Київ-Чоп, Київ-Одеса, Київ-Харків, та відображають основні напрями впливу Києва і його взаємодії з прилеглою територією. Так, у районах, що розміщені уздовж цих магістралей, розміщується особливо значна кількість об'єктів техногенної небезпеки - пожежовибухонебезпечних об'єктів транспортної інфраструктури, передусім АЗС. Наприклад, у Макарівському районі, територією якого проходить автодорога міжнародного значення Київ-Чоп, розміщено 43 об'єкти техногенної небезпеки, тоді як у районному центрі лише один. Це відображає інтенсивність впливу Києва на розвиток району, зокрема роль транспортних артерій, тоді як роль районного центру як осередку активності дуже незначна.

4. Поза приміською зоною характер зосередження небезпечних техногенних об'єктів принципово змінюється: вони переважно розміщуються в містах, які є осередками найбільшої активності. Так, якщо у Вишгородському, Києво-Святошинському, Васильківському Бориспільському, Броварському об'єкти техногенної небезпеки переважно розміщені поза містами (серед районів приміської зони виняток становить лише Обухів, де є своя виражена промзона), то в інших районах Київської області об'єкти техногенної небезпеки передусім пов'язані з містами, що особливо виразно проявляється у периферійних районах області. Окремий випадок - Біла Церква, що формує найбільше зосередження небезпечних об'єктів поза приміською зоною, при цьому маючи свою невелику зону тяжіння, переважно в межах Білоцерківського району, де якраз і зосереджена велика кількість об'єктів.

Таким чином, в Київській області рівень ризиків та стан вразливості території визначаються такими особливостями, як високий рівень диференціації

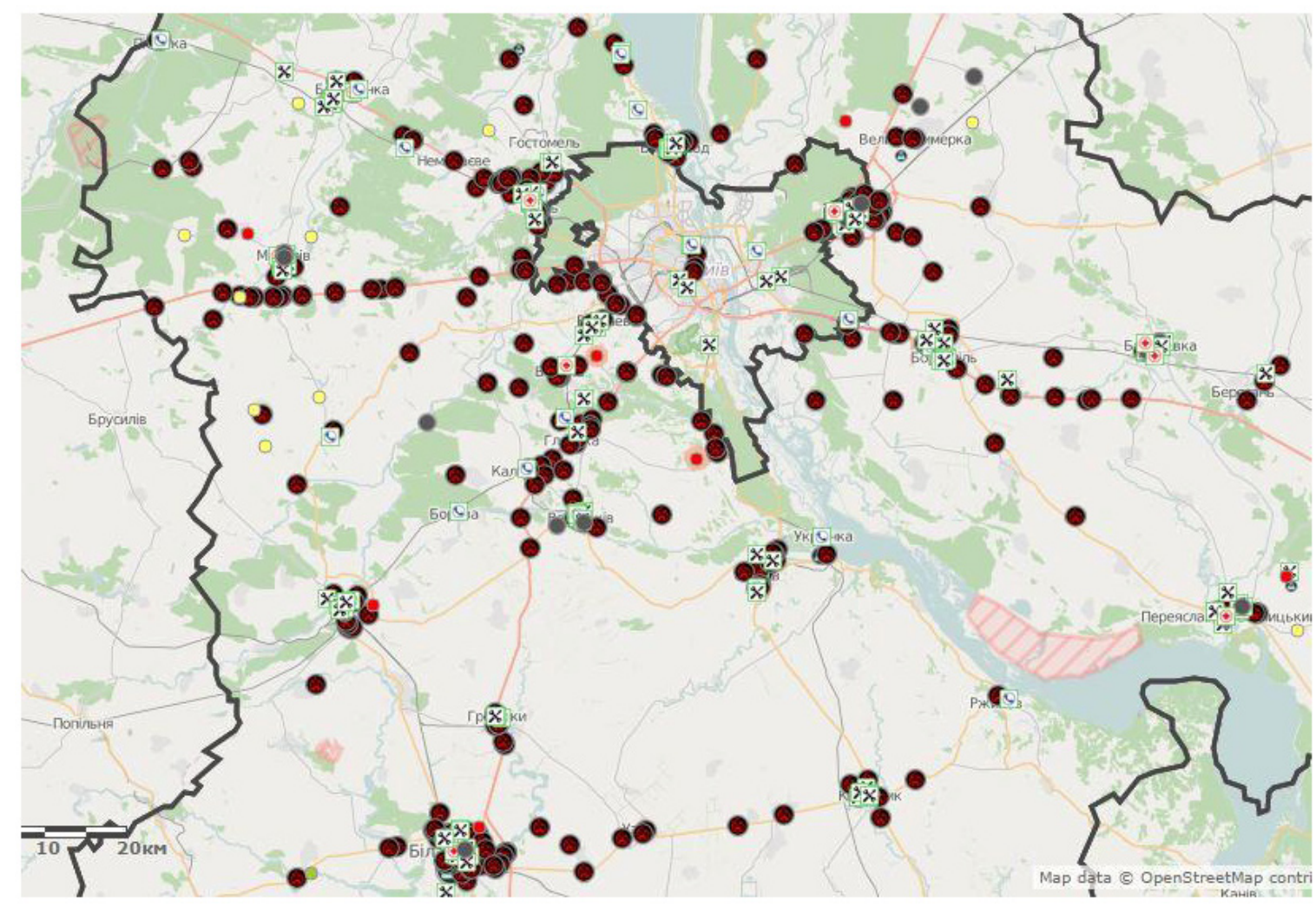

Рис. 1. Локалізація об'єктів техногенного небезпеки та служб реагування в Київській області 
техногенних загроз: у межах приміської території та поза нею, високий рівень чутливості території, а також достатньо висока в масштабі України здатність до пом'якшення ризиків.

Визначені особливості потребують врахування при розробці регіональної стратегії управління ризиками, яка прийматиме їх до уваги та базуватиметься на загальній концепцій їхнього зниження та пом'якшення, а також враховуватиме специфіку та існуючий рівень вразливості території, яка перебуває під впливом великого міста. Орієнтиром при цьому мають бути міжнародні підходи, що на даний час імплементовані в Україні лише частково. Необхідно відзначити, що вони значно відрізняються концептуально, а відповідно, і за змістом управлінського механізму.

До періоду формування міжнародної стратегії зниження ризиків, яка інтенсивно розвивається у світі починаючи з 90-х років, управління у цій сфері передусім стосувалося управління катастрофами та безпосереднього реагування. Водночас один 3 основних аспектів реалізації стратегії - це формування можливостей для попередження небезпек, у тому числі шляхом зміщення акценту 3 реагування на них в сторону запобігання їх виникненню та пом'якшенню ризиків. Оскільки стратегія зниження ризиків визначала доцільність значно ширшого кола підходів 3 метою зниження вразливості території, змістовне наповнення категорії управління теж змінилося, змістився й акцент з управління катастрофами (emergency management) на управління ризиком виникнення катастроф (disaster risk management), що значно розширило можливості реалізації стратегії зниження ризиків. Таким чином, управління ризиками сьогодні, згідно зі світовими стандартами, передбачає системну діяльність, спрямовану як на виявлення та оцінку, так і зниження усіх видів ризиків.

Серед принципових особливостей сучасної концепції управління ризиками - iii величезне соціальне наповнення, що позначило зміну концептуальних, методологічних та методичних підходів. Такі зміни були пов'язані, по-перше, 3 кінцевою метою - зниження вразливості населення, a по-друге, 3 тим, що соціум $є$ безпосередньою дійовою особою, як процесу формування ризиків, так і їх зниження. Без його участі зниження ризиків неможливе: саме рівень усвідомленості ризику суспільством та рівень готовності значною мірою визначають ступінь вразливості території.

За такого підходу істотно трансформується та видозмінюється увесь управлінський механізм, до якого, по-перше, залучаються нові суб'єкти управління, збільшується коло осіб, які приймають

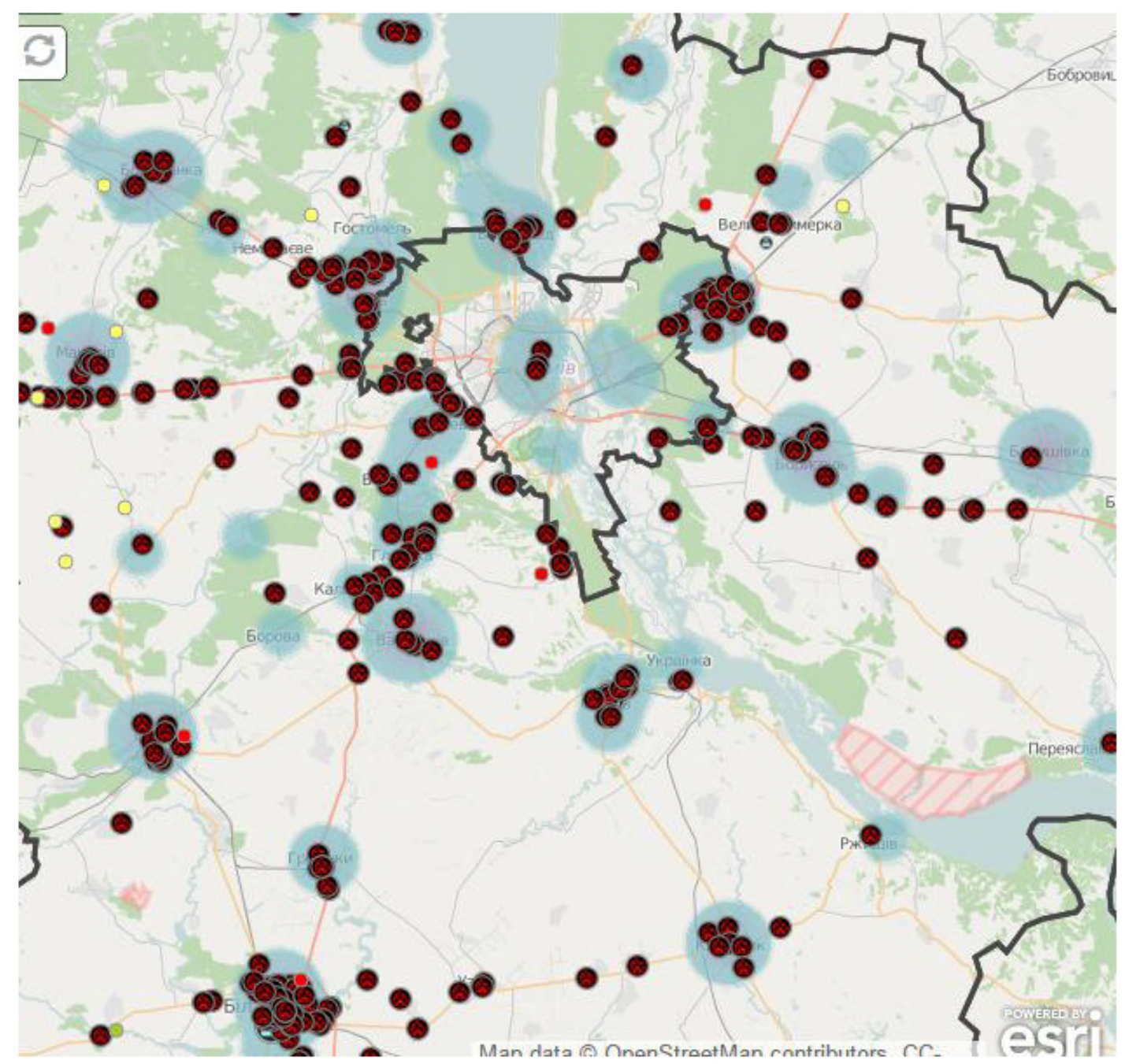

Рис. 2. Розміщення потенційно небезпечних об'єктів та сил реагування у Київській області 
управлінські рішення, по-друге, істотно змінюються існуючі методики оцінку ризику та відбувається розширення його розуміння, зрештою, по-іншому розподіляються ресурси: пріоритетом стає попередження виникнення небезпек, у тому числі завдяки значній диференціації управлінських стратегій відповідно до специфіки території.

В Україні на початку 2014 р. була затверджена Концепція управління ризиками виникнення надзвичайних ситуацій техногенного та природного характеру, в якій частково окреслені деякі ідеї стратегії зниження ризиків. Водночас затвердження такої концепції мало стосувалося змін в управлінському механізмі, окрім того, багато принципових позицій та положень міжнародної стратегії у ній не були враховані. Так, попри те, що метою концепції визначене запровадження сучасних методів управління ризиками, необхідно відзначити, що сучасні, прийняті на міжнародному рівні підходи, навіть на цільовому рівні визначені в концепції лише частково. Серед окреслених - принцип превентивності та свободи інформації. Попри те, що концепція має довгостроковий характер реалізації, як і визначені в ній цілі та засоби їх досягнення, багато принципових положень у ній не були враховані. Серед них найбільш значимими є наступні:

1. Змістовне обмеження i звуження категорії ризику, який розглядається лише як категорія, що характеризує можливість виникнення небезпечної ситуації, що обмежує використання інших методів оцінки та підходів;

2. Об'єктом аналізу, фактично, визначаються окремі джерела небезпеки різних типів, тоді як в усьому світі основним об'єктом стали території різних типів. Лише такий підхід дозволяє здійснити інтегральну оцінку, врахувати специфіку регіону та розробити найбільш адекватну стратегію зниження ризиків;

3. Відсутній принцип просторової багаторівневості при управлінні ризиками, який визначений у міжнародній стратегії та дозволяє враховувати регіональну специфіку при розробці стратегії управління для кожного типу території.

Таким чином, визначені недоліки значно обмежують саму можливість застосування сучасних міжнародних підходів для реалізації механізму управління ризиками, передусім для визначення рівня вразливості території до різних типів ризиків, а відповідно, розробку адекватної до викликів управлінської стратегії.

Процес управління ризиками сьогодні, фактично, являє собою синтез чотирьох етапів: пом'якшення, формування готовності, реагування та відновлення [1]. Необхідно визнати, що найбільш слабкими ланками в Україні серед названих є пом'якшення ризиків та відновлення території після надзвичайних ситуацій, тоді як основні зусилля спрямовані на безпосереднє реагування у випадку настання негативної події.

Загалом управлінський механізм, що реалізується в Україні, за всіма ознаками підпадає під визначення технократичного. До його особливостей належать: централізована вертикально орієнтована модель управління, досить жорстка прив'язаність до технічних показників, переважання кількісних методів аналізу та галузевих оцінок, тоді як роль суспільства досить пасивна і обмежена [4]. Як альтернативний до технократичного, або вертикально орієнтованого, управлінського механізму розглядається людиноцентричний підхід. У межах цього підходу людина в особі громадянського суспільства розглядається як безпосередня дійова особа всього механізму. До його особливостей належить: поєднання кількісних підходів до оцінки ризику з іншими методами їх аналізу, системно орієнтований підхід до оцінки ризиків, розподіл відповідальності за кінцевий результат між багатьма учасниками управлінського процесу, зростання відкритості [4]. Хоча формування цього підходу, особливо його запровадження в чистому вигляді для країн $з$ технократичною моделлю управління, безумовно, не може розглядатися як панацея, окремі складові цього управлінського механізму засвідчили свою досить високу ефективність та поступово мають бути сформовані в Україні.

До пріоритетних задач в контексті реалізації стратегії зниження ризиків можна віднести:

- Залучення громадянського суспільства до участі в управлінському механізмі з метою формування відкритості та поінформованості щодо можливих загроз та основних ризиків, їх пом'якшення;

- Запровадження нових методів оцінки ризиків, спрямованих на виявлення вразливості території до виникнення небезпек та формування стратегій управління ризиками на регіональному та субрегіональному рівнях.

Щодо першого пріоритету, то його запровадження пов'язане 3 необхідністю усвідомленого розподілу відповідальності між державою та громадянським суспільством. Аспектів цієї проблеми, а відповідно i напрямів реалізації цього пріоритету декілька: це i залучення громадських організацій, i побудова ефективної комунікаційної платформи 3 метою формування обізнаності про існуючі ризики, i оцінка сприйняття ризику суспільством та рівня його усвідомленості. Це всі ті аспекти, які можуть, як посилити управлінський механізм та знизити рівень ризиків, так і значно посилити їх у випадку нереалізованості. При цьому стратегічне завдання, що покладається на уряд, в частині формування управлінського механізму, визначення завдань та гарантування прийнятного рівня безпеки на всій території країни лишається незмінним. Пропоновані трансформації механізму управління покликані посилити його слабкі ланки та заповнити існуючи прогалини.

Реалізація другого пріоритету відповідає ідеї врахування ризиків, що проявляються в регіонах різних типів та пов'язані 3 їх оцінкою відповідно до можливих загроз, чутливості території та ii здатності реагувати на загрози, а також відповідно до усвідомлення, що найбільші можливості зниження та пом'якшення ризиків існують на місцевому рівні.

Маючи системні недоліки в механізмі 
управління ризиками на державному рівні, складно реалізувати ефективну регіональну стратегію, особливо 3 урахуванням регіональних особливостей. Якщо для окремих регіонів питання оцінку та врахування вразливості території може бути менш гострим, то для такого регіону, як Київська область, де рівень чутливості є дуже високим, особливо в приміській зоні, його врахування при розробці управлінських рішень та для корегування стратегії $є$ конче необхідним. При цьому одним 3 важливих напрямів реалізації стратегії зниження ризиків, як на регіональному, так і на державному рівні загалом, може бути запровадження широкої комунікаційної платформи, що інформуватиме населення про рівень існуючих ризиків, його просторову диференціацію, основні види та джерела небезпеки, локалізацію потенційно небезпечних об'єктів та доцільну поведінку у випадку настання надзвичайних ситуацій. Сьогодні, окрім відсутності такої платформи для інформування громадськості, навіть інформація, що призначена для управлінських цілей $\epsilon$ неповною, містить ряд неточностей та ставить під сумнів саму можливість реалізації вдалої управлінської стратегії. Так, не лише громадяни недостатньо усвідомлюють рівень існуючих загроз, повною інформацією про них не володіють навіть управлінці. Створення інформаційноаналітичної ГІС покликане вирішити декілька важливих завдань у цьому контексті. Це завдання, спрямовані як на підвищення поінформованості громадян (формування їх обізнаності про існуючі загрози, підвищення рівня готовності до можливих небезпек, а відповідно - пом'якшення ризиків), так і на розширення управлінських можливостей. Остання задача реалізується завдяки нових технічним можливостям просторового відображення різних джерел небезпеки, їх можливого просторового прояву, з урахуванням тих об’єктів, що потрапляють в потенційну зону враження, а також оцінкою сил реагування. Так, на рис. 2 можна, наприклад, прослідкувати, як взаємно накладається розміщення потенційно небезпечних об'єктів у Київській області iз зосередженням сил реагування. Використання подібних аналітичних інструментів розширює управлінські можливості та оптимізує їх, дозволяє розробляти більш ефективні рішення.

Висновки і перспективи подальших розвідок. Виявлені істотні відмінності існуючих в Україні методик оцінки ризику та управління ними потребують корегування та доповнення новими категоріями відповідно до світових стандартів, зокрема запровадження такої категорії оцінки ризику, як вразливість території, що дасть змогу характеризувати його більш глибоко та повно. Потребує зміни і методичне наповнення в частині розширення методів оцінки ризику. У цьому зв'язку має бути принципово змінений управлінський механізм, а нові концептуальні підходи повинні бути відображені, як у загальнонаціональній, так i регіональних стратегіях зниження ризику. Лише формування адекватних деталізованих регіональних стратегій $з$ акцентом на врахування особливостей території може сприяти зниженню ризиків, особливо в таких високих за рівнем вразливості регіонах, як Київська область.

Київська область - це регіон з достатньо високим рівнем ризику до виникнення небезпечних ситуацій, що визначається високим рівнем зосередження потенційно небезпечних об'єктів, особливо на окремих ділянках 3 підвищеним рівнем їхньої концентрації. Водночас рівень загроз зростає у зв'язку 3 високим рівнем вразливості території. Це потребує значного корегування стратегії управління ризиками в регіоні, яка має принципово змінитися в напрямі пом'якшення ризиків та застосування сучасних підходів до формування управлінської стратегії.

\section{References:}

1. Coppola D. Introduction to International Disaster Management (Third Edition), 2015, 760p.

2. ETC-CCA and ETC-SIA (2012). Urban Vulnerability Indicators. Technical report 01/2012.

3. Living with risk. A global review of disaster reduction initiatives. United Nations, New York and Geneva, 2004.

4. Scolobig A., Prior T., Schröter D., Jörin J., Patt A. Towards people-centred approaches for effective disaster risk management: Balancing rhetoric with reality. International Journal of Disaster Risk Reduction, 2015, Vol. 12, pp.202-212.

5. Territorial dynamics in Europe. Natural hazards and climate change in European regions. Territorial Observation, No 7, May 2013.

6. Tingsanchali T. Urban flood disaster management. Procedia Engineering, 2012, Vol. 32, pp. 25-37.

7. UNISDR. Access mode: http://www.unisdr.org. 